\title{
SLIDING STABILITY OF LANDWARD SLOPE CLAY COVER LAYERS OF SEA DIKES SUBJECT TO WAVE OVERTOPPING
}

\author{
A. van Hoven ${ }^{1}$ B. Hardeman ${ }^{2}$ J.W. van der Meer ${ }^{3}$, and G.J. Steendam ${ }^{4}$
}

\begin{abstract}
Sea dikes with landward slopes covered by grass and clay cover layers, subject to wave overtopping, can become unstable and slide. Sliding stability of the cover layer is caused by a decrease in shear strength due to an increase in pore pressure in and underneath the clay cover layer. This holds for both clay dikes and sand dikes with a clay cover layer. A method is presented to determine the potential pore pressure build up due to a storm event with wave overtopping. The method combines of the shelf knowledge and is supported by laboratory measurements and field measurements during prototype scale wave overtopping tests and sliding test on Dutch sea dikes. The method contains three steps: 1) determine the infiltration time, depending on the storm duration and the sea state; 2) determine the infiltration capacity of the dike slope, either by choosing a safe value or field measurement and 3) determine the potential pore pressure build up, determined by step 1) and 2) and the dike structure and geometry. The potential pore pressure build up can be used in the standard stability analyses tools published in Dutch guidelines on dike design and dike safety assessment.
\end{abstract}

Keywords: sliding stability; sea dike; clay cover; infiltration; wave overtopping

\section{INTRODUCTION}

Two wave overtopping related failure mechanisms at dikes or levees are generally distinguished: erosion of the grass and clay cover layer and sliding of the cover layer as a whole. This paper describes the pore pressure build up, which has a large effect on the sliding mechanism. Sliding, parallel to the slope surface, occurs at a typical depth of 0.5 to $1.5 \mathrm{~m}$ beneath the slope surface and starts with a longitudinal fissure near the dike crest. During the 1953 storm surge disaster in the Netherlands, the overwhelming majority of dike failures and damages, $187 \mathrm{~km}$ in total, was caused by sliding of the landward clay cover layer. Analyses of the observed damage led to the Edelman Joustra stability formula for clay covers (Rijkswaterstaat 1961). Other stability formulae, specifically for sand dikes with clay covers and other stability analyses tools, were developed and described (TAW 1995). These stability analysis tools are currently in use for dike design and safety assessment in the Netherlands.

Apart from the slope angle of the landward dike slope, the cover layer stability is dominated by the water pressure underneath the slope surface and the shear strength of the clay, with soil structure. Both parameters are very difficult to determine by traditional small scale laboratory testing. Uncertainties about these parameters lead to excessive designs and, unnecessary, poor safety assessment scores.

The water pressure build up due to wave overtopping was measured in full scale tests with the Wave Overtopping Simulator (Van der Meer et al. 2006, 2008) on sea dikes at five locations in the Netherlands and on one river dike. Apart from the overtopping tests, two sliding tests were performed where a sea dike was subjected to overflow during 56 hours over a length of $30 \mathrm{~m}$ to induce sliding (which did not happen), see Fig. 1.

\footnotetext{
${ }^{1}$ Deltares, P.O. Box 177, $2600 \mathrm{MH}$, Delft, The Netherlands

2 Centre of Water Management, Directorate-General for Public Works and Water Management, P.O. Box 17, 8200 AA, Lelystad, The Netherlands

${ }^{3}$ Van der Meer Consulting b.v., P.O. Box 423, 8440 AK Heerenveen, The Netherlands

${ }^{4}$ Infram b.v., P.O Box 16, 8316 ZG Marknesse, The Netherlands
} 


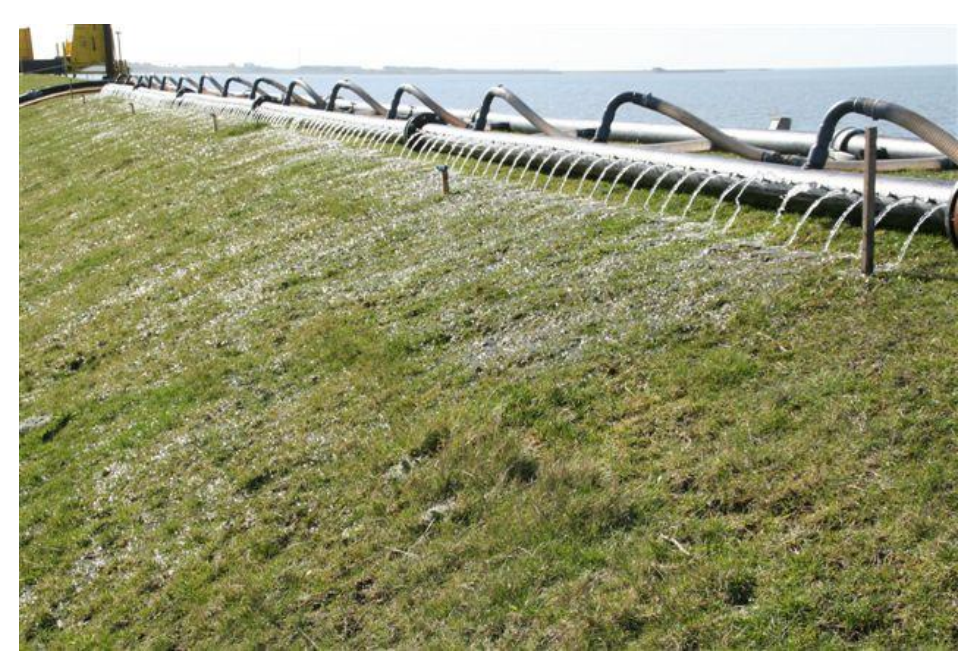

Figure 1. Overflow test on a sea dike over a length of $30 \mathrm{~m}$ during 56 hours to induce sliding.

The field measurements and modeling of infiltration and sliding have led to a better understanding of the process and a method to predict the pore pressure build up due to overtopping and infiltration was deducted. The pore pressure build up due to overtopping can be used in the standard stability criteria of the cover layer. The standard stability analyses methods will not be covered by this paper. The aim of this paper is only to give a guideline to determine the potential pore pressure build up during a storm event with wave overtopping.

\section{CLAY COVER STABILITY}

In order to understand the influence and the characteristics of the pore pressure build up due to overtopping, a short explanation will be given about the cover layer characteristics and stability.

The cover layer is the soil layer, often clay, covering the dike core. A common build up of sea dikes in The Netherlands exists of a sand core, covered by a clay layer of 0.5 to $0.7 \mathrm{~m}$ thick. Some dikes are completely made of clay, in which case the cover layer exists of the upper 1 to $2 \mathrm{~m}$ of clay which has developed soil structure. The soil structure develops in some years after construction of the dike, due to drying in the sun, wetting in the rain, expansion due to frost, digging of small fauna, worm holes and roots penetrating the soil and extracting moisture. Soil structure also develops in clay layers on a sand core, where the whole layer of 0.5 to $0.7 \mathrm{~m}$ will be structured. One of the effects of the soil structure development is the drastic increase in permeability due to fissures and worm holes. The increase in permeability due to the soil structure development will be much higher in vertical direction than in horizontal direction.

Soil structure development also has an effect on the shear strength of the soil. The aggregates, small and loosely packed near the slope surface, large and densely packed deeper down, can have bulk shear strength characteristics, which are different than the characteristics of the base material. A proper method to determine the shear strength of clay with soil structure has not yet been developed. Standard tri-axial tests, typically performed on $60 \mathrm{~mm}$ diameter samples, are too small to incorporate the larger aggregates. Furthermore the standard tri-axial test procedure involves full saturation of the material, with the aid of $\mathrm{CO}_{2}$ flushing and a large back pressure to reduce remaining air bubbles. In the case of wave overtopping, the large structures will be saturated, however, the aggregates will to some extend still have suction stresses inside and remain firm. A study comparing large tri-axial tests with a saturation procedure similar to a wave overtopping situation, with standard tri-axial tests seems to suggest standard tests will not underestimate the shear strength of the clay with soil structure. The results are, however, not generally conclusive (Van Hoven, 2008).

Instability of the clay cover layer on the landward slope can exist of sliding parallel to the slope or uplift perpendicular to the slope, depending on the dike construction. In case of a clay dike only sliding parallel to the slope can occur. In case of a sand dike with a clay cover, both sliding and uplift can occur (Fig. 2). In this case sliding can also be induced by an uplift pressure underneath the clay 
cover layer, which reduces the effective stress on the cover layer and sand core boundary. Stability of the cover layer in perpendicular direction might still be sufficient, however, the reduced effective stress along the boundary reduces the stability in parallel direction as well, and can become critical.

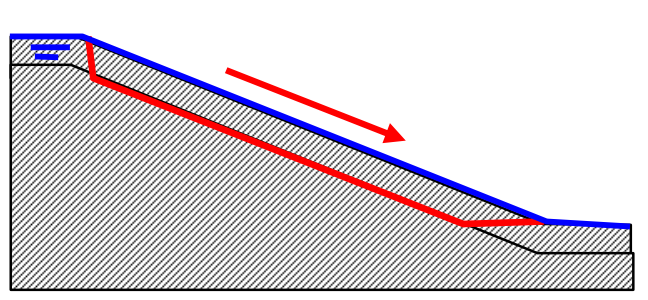

Clay dike - sliding parallel to slope

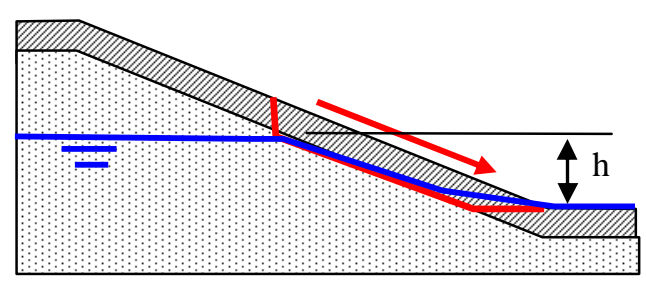

Sand dike with clay cover sliding parallel to slope

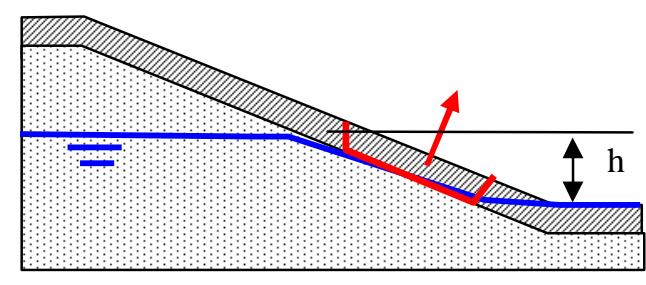

Sand dike with clay cover uplift

Figure 2. Sliding and uplift of the clay cover layer in case of a clay dike and a sand dike with clay cover

For a clay dike (top in Fig. 2.) the stability becomes critical if the cover layer with soil structure becomes fully saturated and a ground water flow parallel to the slope surface develops. The vertical infiltrating of water will be hindered by the decrease in permeability when the infiltration front reaches the dike core and will start to flow parallel to the slope. The stream lines are parallel to the slope and lines of equal pressure head are perpendicular to the slope. The pressure $\mathrm{p}\left(\mathrm{N} / \mathrm{m}^{2}\right)$ distribution underneath the slope surface becomes $\mathrm{p}(\mathrm{z})=\rho_{\mathrm{w}} * \mathrm{~g} * \mathrm{z} * \cos \alpha$, where $\rho_{\mathrm{w}}\left(\mathrm{kg} / \mathrm{m}^{3}\right)$ is the volumetric mass of water, $g\left(\mathrm{~m} / \mathrm{s}^{2}\right)$ the gravitational acceleration, $\mathrm{z}(\mathrm{m})$ the depth, perpendicular, underneath the slope surface and $\alpha$ the slope angle. This pressure distribution will be called $p_{\text {parallel. }}$ A pore pressure larger than $\mathrm{p}_{\text {parallel, }}$, indicates an outward gradient, which is unfavorable for stability. A pressure lower than $p_{\text {parallel }}$ indicates either an inward gradient, or the cover layer is not completely saturated, both of which are favorable for stability

For a sand dike with a clay cover layer (bottom in Fig. 2.) the vertical infiltration will not be hindered by the sand core, because the permeability of the sand is of the same order as the (vertical) permeability of the clay cover layer with soil structure. As long as the vertical infiltration is not hindered or blocked by less permeable layers, there will be no significant increase in pore pressure. The water will seep through the dike core adding water to the initial water table. The rising ground water level inside the dike core can cause instability of the cover layer, either by sliding or by uplift. The ground water level above the dike toe $\mathrm{h}(\mathrm{m})$ is the main parameter in the stability analyses of the cover layer. Note that the added water due to infiltration of overtopping water must be added by a possible water table elevation due to the high water level against the outer slope of the dike and that water will also infiltrate in permeable sections of the outer slope and dike crest.

\section{CURRENT GUIDELINES}

Current guidelines on the mechanism of sliding of the landward slope cover layer due to wave over topping is as follows: 
Step 1 - The mechanism will not occur if:

there is no significant over topping discharge, which means less than $0.1 \mathrm{l} / \mathrm{s}$ per ' $\mathrm{m}$, regardless of the sea state causing the overtopping, or

the slope is less steep than $1 \mathrm{~V}: 4 \mathrm{H}$.

Step 2 - If the conditions in step 1 are not met, the stability of the cover layer should be checked with the stability analyses tools in TAW 2001. For a clay dike a ground water table co-insiding with the slope surface should be assumed if the average overtopping discharge is larger than $0.1 \mathrm{l} / \mathrm{s}$ per ' $\mathrm{m}$. This is regardless of the sea state causing the overtopping. For a sand dike with a clay cover layer no guideline is given to determine the potential rise of the ground water table inside the dike core.

The uncertainties in determining the potential water table rise can lead to excessive dike design or pore safety assessment scores.

\section{THREE STEP METHOD TO DETERMINE PORE PRESSURE BUILD UP}

The three step method given below, aims to determine the pore pressure build up due to wave overtopping, filling the gap left in the second step of the current guidelines. The method incorporates available knowledge about wave overtopping volume distributions, depending on the sea state causing the wave overtopping, infiltration time caused by overtopping volumes and knowledge about infiltration.

The first step is to determine the infiltration time (s). Infiltration will only occur of there is a water layer on the slope surface. An overtopping volume during a storm will supply a water layer for some time, after which the slope dries, or a following overtopping volume will wet the surface once more. The added time a water layer is present during a storm is the infiltration time.

The second step is to determine the infiltration capacity of the slope surface $\left(\mathrm{m}^{3} / \mathrm{s} \mathrm{per} \mathrm{m}^{2}\right)$. The infiltration capacity determines the volume of water which can infiltrate per unit of time, if there is a water layer on the slope surface to supply the water.

The third step is to determine the potential pore pressure build up. The infiltration time, determined in step 1, multiplied by the infiltration capacity determined in step 2, results in an infiltrating volume. For clay dikes the infiltration volume must be compared to the volume of large pores, caused by soil structure development, to determine if full saturation is possible. For sand dikes the infiltration volume, divided by the sand porosity, will give the potential ground water level rise.

Each step will be clarified in depth in the following sections.

\section{STEP 1 - INFILTRATION TIME}

Infiltration will only take place if there is a water layer on the inner slope surface. The water layer thickness can be small. Even a few mm thickness, which is hardly visible in between the grass cover, is sufficient. The amount of time during a storm that there is a water layer present on the slope surface is the most important factor for infiltration.

Each overtopping volume will, in average, result in a water layer during somewhat less than $30 \mathrm{~s}$. This is called the (water) supply time. The supply time was measured visually at wave overtopping tests on Dutch dikes, with slopes ranging from $1 \mathrm{~V}: 2.3 \mathrm{H}$ to $1 \mathrm{~V}: 3 \mathrm{H}$. At a dike sloped $1 \mathrm{~V}: 4.5 \mathrm{H}$ the water supply time was about $40 \mathrm{~s}$ per wave overtopping volume.

The overtopping volume does not seem to be important for the supply time. Large volumes, up to $5,500 \mathrm{l} / \mathrm{m}$, gave roughly the same supply time as the smaller ones. Only the very small volumes of less than 50 to $100 \mathrm{l} / \mathrm{m}$ gave shorter supply times. This effect will not be considered further, giving some unknown margin of safety.

An average wave overtopping discharge exists of a distribution of overtopping wave volumes. The same average overtopping discharge can be a result of a few very large overtopping volumes or a lot of smaller ones, depending on the sea state responsible for the overtopping discharge. A small wave height and period will result in a lot of small overtopping wave volumes, while a large wave height and period will result in a few large overtopping volumes. In case of a small wave height and period, the period in between overtopping volumes will be less than $30 \mathrm{~s}$ and thus a constant water supply for infiltration. In case of a large wave height and period the slope surface can dry in between overtopping volumes. This effect can be calculated using the formulae from TAW 2002 and is given in Fig. 3. 
The graph in Fig. 3. is constructed by Monte-Carlo simulation. Every average wave period (s) a wave reaches the outer slope. Each of these waves has a certain probability of giving a wave overtopping event, which can be calculated using the formulae from TAW 2002. If the wave overtops, the slope will be wet for $30 \mathrm{~s}$. If within $30 \mathrm{~s}$ there is another wave overtopping event, the slope will stay wet for another $30 \mathrm{~s}$, otherwise, after $30 \mathrm{~s}$ the slope will become dry until a following overtopping event takes place.

Fig. 3. gives the infiltration time as a percentage of the sea state time on the vertical axis. The graph is valid in case of a $1 \mathrm{~V}: 4 \mathrm{H}$ outside slope, roughness factor 1.0 and a wave steepness of $0.05(-)$ considering the wave peak period and the wave length on deep water. The lines in the graph represent different average overtopping discharges. On the horizontal axis the significant wave height $\mathrm{H}_{\mathrm{s}}(\mathrm{m})$ is given.

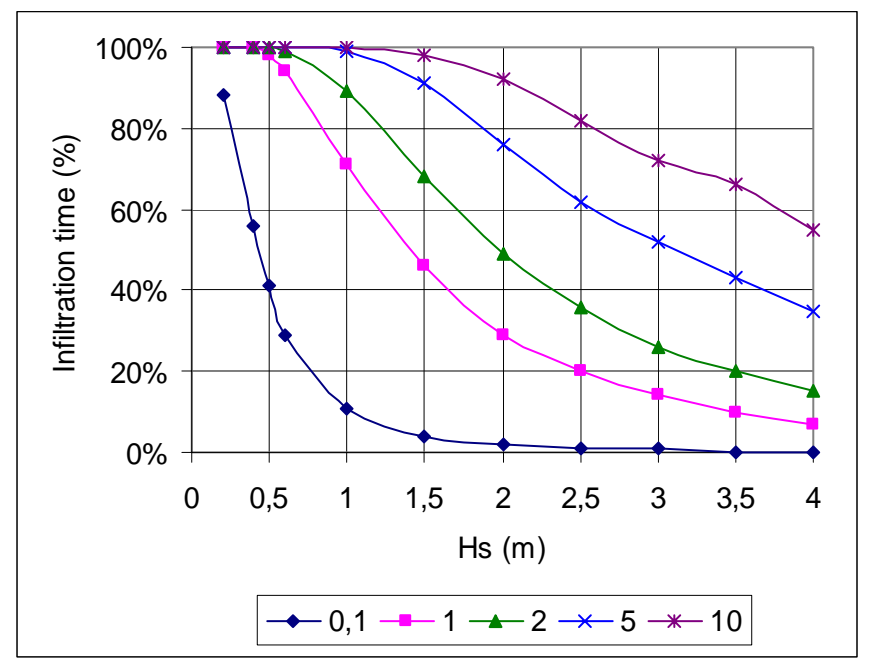

Figure 3. Infiltration time as a percentage of sea state duration (\%) for different average overtopping discharges (0.1-1-2-5-10 I/s per ' $\mathrm{m}$ ) and different $H_{s}(\mathrm{~m})$, valid for an outer slope 1:4, roughness factor 1 and a wave steepness $0.05(-)$.

For example, considering a sea state with a significant wave height of $1 \mathrm{~m}$ and an average overtopping discharge of $21 / \mathrm{s}$ per ' $\mathrm{m}$, will result in an infiltration time of $90 \%$ of the sea state time. If the average overtopping discharge is caused by a $3.5 \mathrm{~m}$ significant wave height, the infiltration time would be $20 \%$.

For different wave steepness and/or outer slope geometries, other graphs can be made. The graph presented in Fig. 3. is safe to use, e.g. results in a high estimate of infiltration time, for the most common cases of Dutch dikes.

\section{STEP 2 - INFILTRATION CAPACITY}

The infiltration capacity is the amount of water per unit of time that can infiltrate into the slope surface given the presence of a water supply on the slope surface. The higher the infiltration capacity the more water enters the dike, which can lead to stability problems. The infiltration capacity of clay with soil structure is generally in between $1 \times 10^{-5}$ and $1 \times 10^{-4} \mathrm{~m}^{3} / \mathrm{s}$ per $\mathrm{m}^{2}$ (TAW 1996). This infiltration capacity was measured by field tests on dozens of Dutch dikes.

Within the framework of the wave overtopping tests in the period 2007-2010 (see acknowledgements), 21 field infiltration tests were performed on six different locations, one clay dike, four sand dikes with a clay cover layer and one sand dike. The test results agree with the earlier results from TAW 1996, regardless of the type of dike. The infiltration capacity of the sand dike was in the same order as the clay dike and the sand dikes with clay cover layer.

The field infiltration tests consisted of pressing a $0.4 \mathrm{~m}$ diameter steel tube vertically into the slope surface, using a hydraulic crane, to a depth equal to the cover layer thickness. A known volume of water would be placed into the tube, after which, during a couple of hours, the decrease in water 
level inside the tube would be measured. Dividing the water level decrease by the time it took, results directly in the infiltration capacity. The measurement can also be used to obtain the saturated permeability for more advanced infiltration calculations, not covered by this paper. The method to obtain the saturated permeability and a description of some of the 21 performed field infiltration tests is given in (Van Hoven and Barends 2010).

An infiltration capacity of $1 \times 10^{-4} \mathrm{~m}^{3} / \mathrm{s}$ per $\mathrm{m}^{2}$ is generally a safe first estimate. Field infiltration tests can be used to determine a more accurate and probably a lower value. For example, the average of the 21 field infiltration tests was $2.4 \times 10^{-5} \mathrm{~m}^{3} / \mathrm{s}$ per m $\mathrm{m}^{2}$, where the largest value was $0.6 \times 10^{-4} \mathrm{~m}^{3} / \mathrm{s}$ per $\mathrm{m}^{2}$. The infiltration capacity for clay dikes, sand dikes with a clay cover layer and even the sand dike did were not significantly different from each other. The soil structure development in the clay causes an increase in permeability relative to the base material, which is in the range of the commonly found fine sands used for dike (core) construction in The Netherlands.

Finally, the infiltration volume due to infiltration caused by wave overtopping is equal to the infiltration time (Step 1) multiplied by the infiltration capacity (Step 2).

It is noted that standard laboratory permeability tests on small, standard sample sizes (ca. 60 $\mathrm{mm}$ ), are inadequate to determine the infiltration capacity of clay with soil structure. The results of standard laboratory falling head or constant head tests will lead to a large underestimation of the infiltration capacity, and therefore underestimating the potential pore pressure build up inside and underneath the cover layer.

\section{STEP 3 - POTENTIAL PORE PRESSURE BUILD UP}

The potential pore pressure build up due to infiltration of overtopping water depends, apart from the infiltration volume, on the dike structure and geometry. As long as the vertical infiltration of water continues and the infiltration front does not meet significantly less permeable layers, no pressure build up occurs which might lead to stability problems. However, as soon as the infiltration front reaches a barrier (less permeable layer) or the initial ground water table, the pore pressure can increase and cause instability if the shear strength is not sufficient, relative to the slope angle. To determine the potential pore pressure build up two cases must be distinguished:

Clay dike

Sand dike with clay cover layer.

In case 1 , a clay dike, the clay core acts as a barrier. When the infiltration front, which moves vertically trough the soil structure, reaches the clay core, pressure will build up, as the vertical infiltration stops and the ground water flow becomes parallel to the slope surface. The parallel ground water flow situation meets the pressure distribution assumption in the standard stability criterion by Edelman and Joustra as mentioned earlier.

The minimum requirement to reach this situation is if the infiltration volume, as determined in step 2, is enough to fill the larger pores, or macro pores, of the soil structure. A safe estimate for typical Dutch clay dikes is 125 liter per $\mathrm{m}^{2}$. The value can also be determined by laboratory testing on large samples. The testing procedure is not covered by this paper. If the infiltration value is equal to or larger than the volume of the macro pores, it should be assumed a ground water flow parallel to the slope has developed and the standard Edelman and Joustra criterion must be applied to determine if the stability of the cover layer is sufficient.

The soil structure development depends on many factors, such as: the physical and chemical characteristics of the base material (clay), the water content when the dike was built, precipitation and evaporation, frost and effects of flora and (small) fauna - mice, insects and worms - living in the upper soil layers. However, research within the framework of TAW 1996, has led to a fairly generally applicable soil structure build up for Dutch dikes, given in Table 1. Exceptions are dikes where the clay cover layer was built with a much too high water content. In this case wide fissures, appearing shortly after dike construction, will not close anymore as the soil structure develops. 


\begin{tabular}{|c|c|c|}
\hline Depth (m) & Aggregates description & Macro pores \\
\hline $0-0,05$ & Very small, very loose, kept together by roots & $>30 \%$ \\
\hline $0,05-0,2$ & $0,1-3 \mathrm{~cm}$, Loosely packed & $20-30 \%$ \\
\hline $0,2-0,4$ & $3-6 \mathrm{~cm}$, loose fit & $5-20 \%$ \\
\hline $0,4-0,8$ & $5-15 \mathrm{~cm}$ elongated, tight fit. & $2-5 \%$ \\
\hline$>0,8$ & Vertical fissures & $<2 \%$ \\
\hline
\end{tabular}

Given the amount of macro pores from Table 1, the low estimate of the macro pores results in a required 60 liters per $\mathrm{m}^{2}$, while the high estimates will lead to 120 liters per $\mathrm{m}^{2}$. An unfavorable situation when considering the cover layer stability would arise if the soil structure development would penetrate deeper. Doubling the layer thickness and using the lower estimates of the macro pores results in the earlier mentioned volume of 125 liter per $\mathrm{m}^{2}$ to saturate the cover layer up to $1.6 \mathrm{~m}$.

If the infiltration volume is less than the volume of macro pores, the macro pores will not fully saturate, which is favorable for the cover layer stability. Before the infiltration front has reached the dike core, the storm event will have stopped, diminishing the probability of dike failure by the mechanism of cover layer sliding.

In case 2. a sand dike with a clay cover layer, the core is as permeable as the vertical permeability of the clay cover layer, with soil structure, and is no barrier to the infiltration front. In this case, the infiltration front will reach the initial ground water level, rising it as water is added. In this case it is important to realize that the infiltrating water will follow preferred paths of low resistance through the dike. Tests within the framework of TAW 1996 have shown that the largest portion of infiltration will follow only a few large fissures and wormholes. The infiltration front will not, as a wide front, reach the initial water table, but some preferred paths will start to feed water to the initial water table and thus rising it. Air inclusions inside the sand core will influence the path the water flows and also influence the infiltration rate. Ignoring the effect of air inclusions is a safe one.

The potential rise of the initial ground water level is equal to the infiltration volume, determined in step 2, divided by the effective sand porosity (free volume of voids/volume of sand). The porosity of sand is generally around 0.4 when no special care has been taken to compact the sand. In the field, the sand inside a dike above the ground water table will be moist. The water content from sand samples taken from dikes range from $4-12 \%$, which means up to about $25 \%$ of the pores in the sand are already filled by water and $75 \%$ remains to be filled to reach full saturation. The effective porosity is therefore about $0.3(-)$.

Again it is noted that the ground water level rise due to infiltration by wave overtopping must be added to any rise due to a high water level on the outer slope or other causes.

The total ground water level rising, due to infiltration and by other causes, can be used in the stability analyses tools for sand dikes with clay cover layers as described in TAW 2001.

\section{VALIDATION TESTS}

Pressure measurements, in and underneath the (clay) cover layer, have been taken during wave overtopping tests at 6 dikes in the Netherlands, one clay dike, four sand dikes with clay cover layers and one sand dike. Because the wave overtopping tests, primarily performed to induce erosion failure of the grass sod, were only $4 \mathrm{~m}$ wide, the pressure build up inside the dike core was too much influenced by 3D effects. Only measurements up to $1 \mathrm{~m}$ underneath the slope surface gave usable validation data.

The wave overtopping test consisted of an increasing average discharge $0.1-1-10-20-30-$ $50-75 \mathrm{l} / \mathrm{s}$ per ' $\mathrm{m}$ given a sea state with $\mathrm{H}_{\mathrm{s}}=2 \mathrm{~m}$. At some locations some average discharges were skipped. Each of the sea states was simulated during 6 hours.

Apart from the wave overtopping tests, two sliding tests were performed over a $30 \mathrm{~m}$ wide dike section. The two dike sections, both a sand dike with a clay cover layer, were subjected to overflow during 56 hours at such a discharge that the full slope was constantly wet. 


\section{VALIDATION OF A CLAY DIKE}

The research was aimed specifically at sea dikes, where overtopping is much more important than at river dikes. Because most sea dikes are made of sand with a clay cover layer, only one full clay dike was tested, near Delfzijl in the North of The Netherlands. The wave overtopping load existed of an increasing average overtopping discharge, given a $\mathrm{H}_{\mathrm{s}}=2 \mathrm{~m}$ sea state. Each average discharge, $0.1-1$ $10-20-30-50 \mathrm{l} / \mathrm{s}$ per ' $\mathrm{m}$, was maintained for 6 hours, which is a high estimate for a design overtopping event duration. Pressure measurements were taken at two locations along the slope surface and at two depths relative to the slope surface $(0.8 \mathrm{~m}$ and $1.2 \mathrm{~m})$. During the wave overtopping tests the pressure would rise. For each overtopping test the maximum pressure $p_{\max }$ was determined and calculated as a percentage of $\mathrm{p}_{\text {parallel }}$. The results are given in Fig. 4.

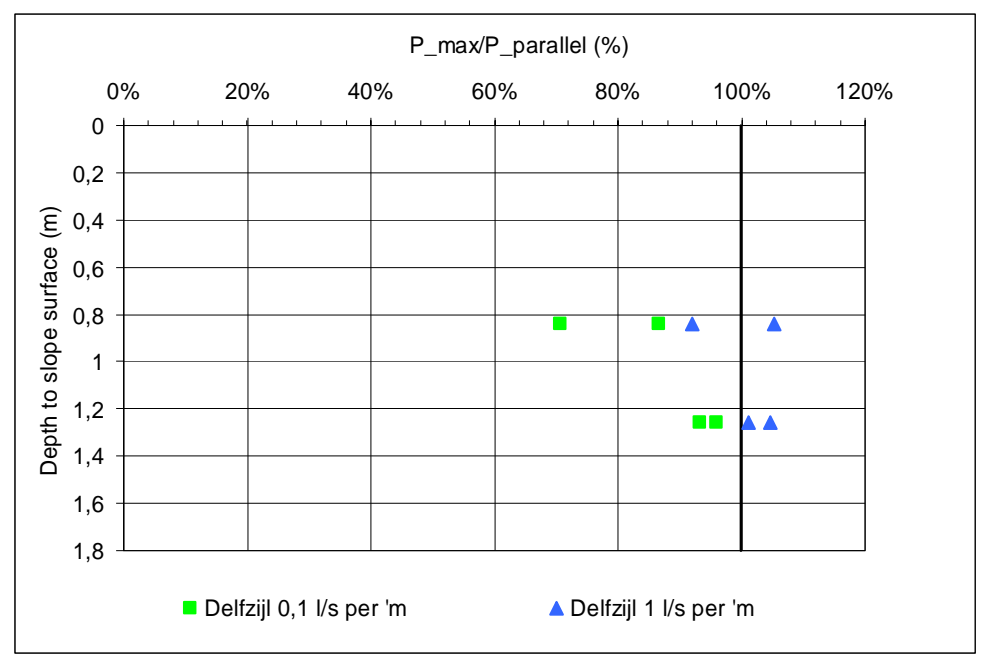

Figure 4. $p_{\max } / p_{\text {parallel }}(\%)$ measured at two depths relative to the slope surface $(m)$ on two locations during prototype scale wave overtopping tests at Delfzijl

As can be seen from Fig. 4., the assumed parallel flow condition is not yet reached for the $0.1 \mathrm{l} / \mathrm{s}$ per ' $\mathrm{m}$ test, but is reached for the $1 \mathrm{l} / \mathrm{s}$ per ' $\mathrm{m}$ test.

The infiltration time, given the simulated $\mathrm{H}_{\mathrm{s}}=2 \mathrm{~m}$ sea state, can be read from Fig. 3 and is $4 \%$ for $0.1 \mathrm{l} / \mathrm{s}$ per ' $\mathrm{m}$ and $30 \%$ for $1 \mathrm{l} / \mathrm{s}$ per ' $\mathrm{m}$ of the simulated sea state duration of 6 hours, resulting in 0:14:24 and 1:48:00 hours respectively (Step 1). With an infiltration capacity of $1 \times 10^{-4} \mathrm{~m}^{3} / \mathrm{s}$ per $\mathrm{m}^{2}$ the infiltration volume becomes $86 \mathrm{l} / \mathrm{m}^{2}$ and $648 \mathrm{l} / \mathrm{m}^{2}$ respectively (Step 2). During the $0.1 \mathrm{l} / \mathrm{s}$ per ' $\mathrm{m}$ test the infiltration volume remains below the critical value of $125 \mathrm{l} / \mathrm{m}^{2}$, while during the $1 \mathrm{l} / \mathrm{s}$ per ' $\mathrm{m}$ test the critical value is exceeded. This is in line with the measurements shown in Fig. 4.

\section{VALIDATION OF A SAND DIKE WITH CLAY COVER LAYER}

Because of the reasons given above (see section VALIDATION TESTS), the best usable validation data from the wave overtopping tests on sand dikes with a clay cover layer comes from measurements inside and just underneath the cover layer. These pore pressures should stay below the value of $\mathrm{p}_{\text {parallel }}$, for any average overtopping discharge. The test results are plotted in the same way as stated in the section VALIDATION OF A CLAY DIKE and are given the graphs in Fig. 5. Note that the negative values of $\mathrm{p}_{\max } / \mathrm{p}_{\text {parallel }}$ indicates suction stress, and thus saturation less than $100 \%$. 


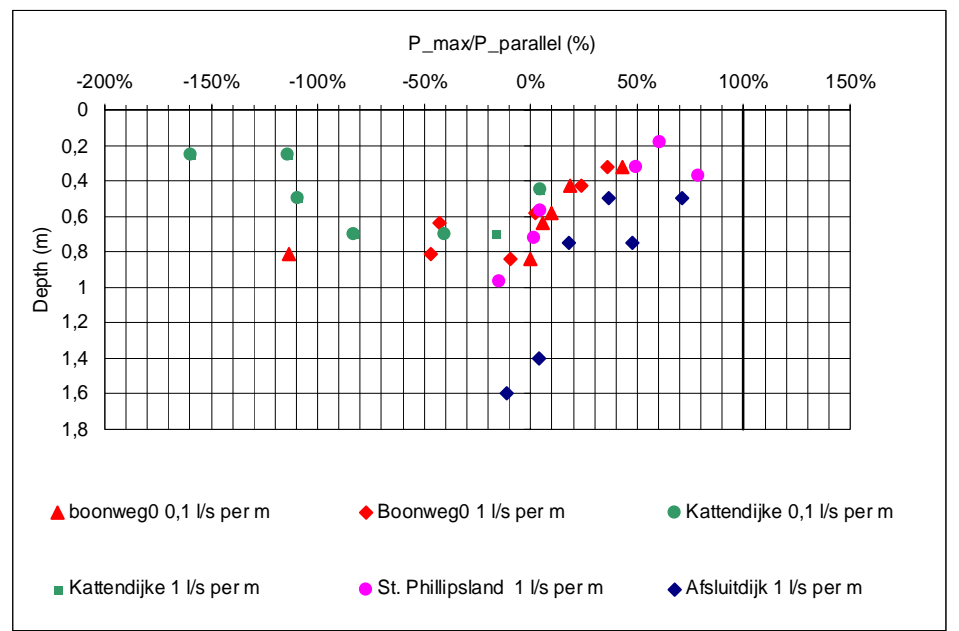

0.1 and $11 / \mathrm{s}$ per ' $m$ tests

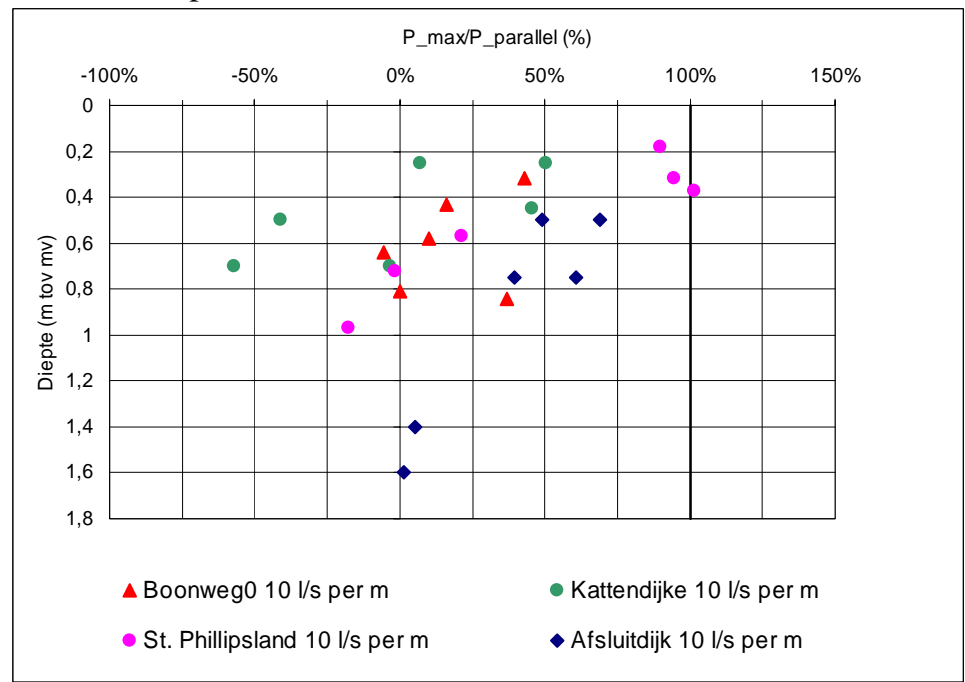

\section{$10 \mathrm{l} / \mathrm{s}$ per $\mathrm{m}$ tests}

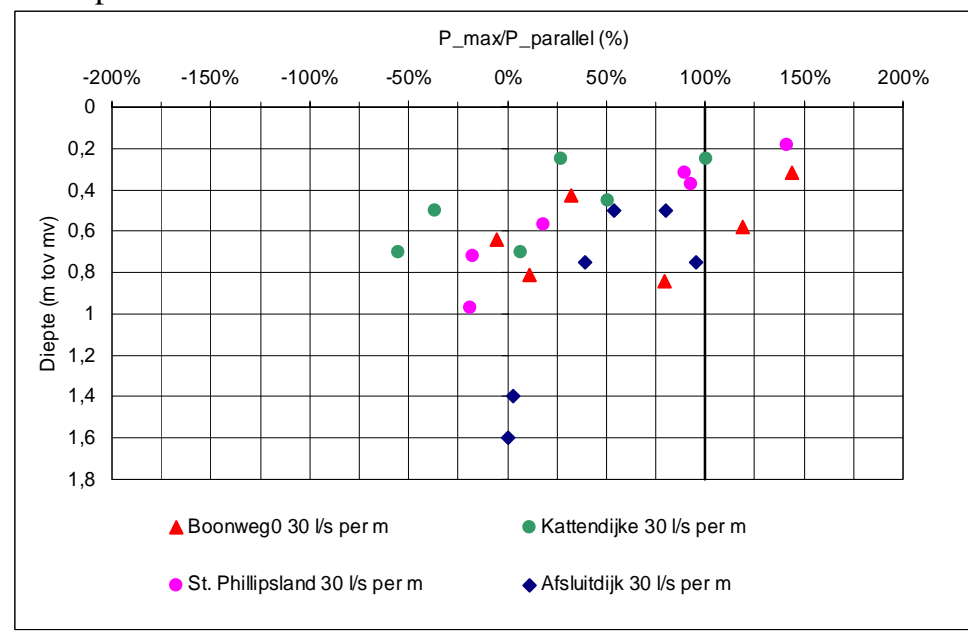

$301 / \mathrm{s}$ per 'm tests

Figure 5. $p_{\max } / p_{\text {parallel }}(\%)$ measured at different depths relative to the slope surface $(m)$ on sand dikes with a clay cover layer. 
The graphs in Fig. 5. show that the pressure measurements are below the critical value of $\mathrm{p}_{\text {parallel }}$ for the 0.1 and $1 \mathrm{l} / \mathrm{s}$ per $\mathrm{m}$ wave overtopping tests. However, at the $10 \mathrm{l} / \mathrm{s} \mathrm{per} \mathrm{'} \mathrm{m}$ test, one of the pressure transducers at location 'St. Phillipsland' reaches the critical value. At $30 \mathrm{l} / \mathrm{s}$ per 'm also the locations 'Boonweg' and 'Kattendijke' reach the critical value and go beyond the critical value. For higher average overtopping discharges, the pressures generated by the tests are less than at 30 1/s per ' $m$, probably due to effects of clogging of the macro pores.

The higher than $p_{\text {parallel }}$ pressures were not predicted by the presented 3 - step method. The high pressures indicates a local outward gradient in pressure head, which is unfavorable for the stability of the clay cover layer at that location. It should, however, be noted that the higher pressure is only measured at one location on the slope surface, while at the other location on the slope surface during the same tests the pressure remains well below the critical value. The soil structure build up is such that relatively large variations in permeability exist and influence the measurements, which are point measurements. The measurements do not show that the bulk of the pore pressure inside the clay cover layer exceeds the critical value, which would be required to cause stability problems.

Apart from the wave overtopping tests, two sliding tests were performed (see section VALIDATION TESTS). Both tests were performed on sea dikes along the Waddenzee in the North of The Netherlands, the first location 'Boonweg' and the second 'Afsluitdijk'. Both dikes can be categorized as sand dikes with a clay cover layer, although the 'Afsluitdijk', has a 1,5 m thick cover layer build up of a $1 \mathrm{~m}$ thick layer of loam topped by a $0,5 \mathrm{~m}$ thick clay layer. According to the safety assessment of this dike, carried out in 2005, the clay layer was susceptible to sliding over the loam layer in case of overtopping. Sliding of the clay layer over the loam layer would mean a clay dike type failure mechanism. The results of the 'Afsluitdijk' sliding test are in line with the 3-step method, however, the results will not be dealt with in detail in this paper.

During the tests the pressure head inside the dike sand core was monitored at four points. Also the pore pressure in the clay cover layer and just beneath, in the sand core was monitored. The results of the measurements and the evaluation of the tests were reported within the framework of SBW (see ACKNOLEDGEMENT). In this paper only the main results will be given.

The first test was performed at 'Boonweg'. The infiltration time was equal to the test duration of 56 hours, because the dike was loaded by overflow instead of wave overtopping (Step 1). The infiltration capacity was determined by 6 field infiltration tests and was found to be $2,4 \times 10^{-5} \mathrm{~m}^{3} / \mathrm{s}$ per $\mathrm{m}^{2}$ (Step 2). The infiltration volume is $56(\mathrm{hr})^{*} 3600(\mathrm{~s} / \mathrm{hr})^{*} 2,4 \times 10^{-5}\left(\mathrm{~m}^{3} / \mathrm{s}\right.$ per $\left.\mathrm{m}^{2}\right)=4,8 \mathrm{~m}^{3}$ per $\mathrm{m}^{2}$. The effective permeability was determined by laboratory testing and was found to be 0,32 (-). The potential rise of the ground water level would be $4,8 \mathrm{~m} / 0,32=15 \mathrm{~m}$ (Step 3). According to the presented 3-step method the rate of increase of the ground water level would be $0,27 \mathrm{~m}$ per hour. The dike would become completely saturated at the end of the test, and stability problems were predicted even after 12 hours into the test (It is noted the prediction for the test was made with the Van Genuchten model for unsaturated ground water flow incorporated in PlaxFlow, combined with the FEM stability tool Plaxis). Because the sliding failure mechanism was the object of the test, the test duration was chosen much longer than would be required according to the prediction.

The measured pressure head inside the sand core is given in Fig. 6. Three signals are given, taken from the middle of the $30 \mathrm{~m}$ wide dike section which subject to overflow. The pressure transducers are placed inside the sand core, at a depth beneath the ground water level under daily circumstances. The first (red) is located half way down the slope, the third (blue) is located at the dike toe and the second (green) is placed in between. 


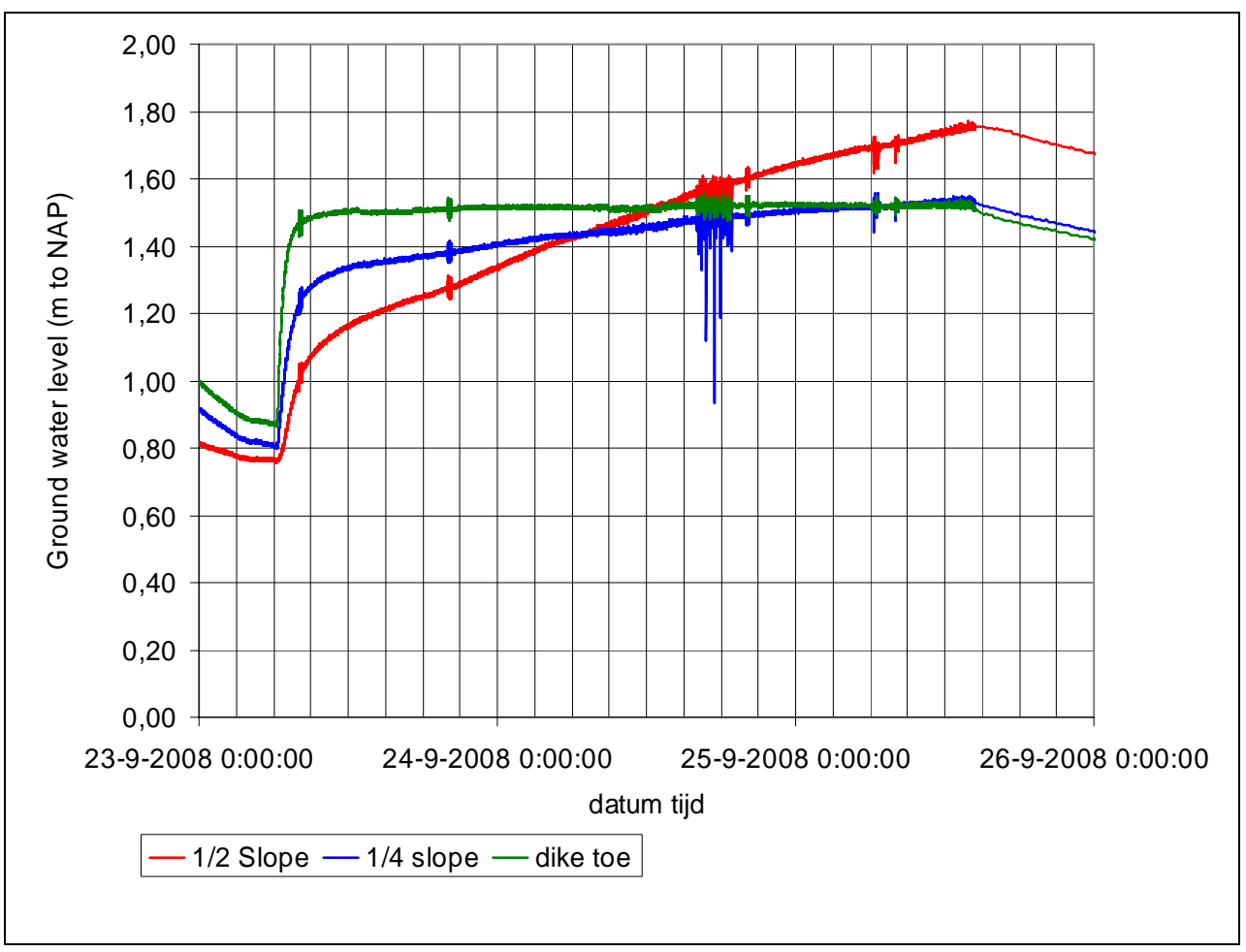

Figure 6. Measurements of pressure head ( $m$ to NAP) during sliding test at location 'Boonweg'

The measurements show a fast increase in the pressure head, almost equal to $0,27 \mathrm{~m} / \mathrm{hour}$, as predicted above. After about 3 hours the rate drops drastically. The pressure transducer at the toe of the dike at that moment reached its limit, namely the dike toe level. The pressure transducers at $1 / 4$ and $1 / 2$ the slope still increase, however, at a very low rate. The predicted ground water level, both by the 3step method and the advanced Van Genuchten (in PlaxFlow) model, was never reached and sliding did not occur. The probable cause was a much larger than expected 3D effect due to a larger horizontal than vertical permeability of the sand core. A volume of water analyses revealed a substantial loss of water from the test site.

The measurements do however show, that the 3-step method provides an estimate on the safe side. The measured maximum rate of increase of the ground water level did not exceed the predicted one and even predicted the ground water level rise quite well at the start of the test.

\section{ACKNOWLEDGMENTS}

The research was carried out within the framework of the SBW-program (Strength and loads on water defenses) by the Dutch Ministry of Transport, Public works and Water Management.

\section{REFERENCES}

References by TAW are sometimes available in English, however, the quality of the translations is not very high. For this paper the Dutch versions were used. Dutch versions of the reports in pdf format are freely available on the internet by google-ing the title in Dutch. English versions of the reports in pdf format, if available, can be obtained by contacting the author of this paper, or first check www.enwinfo.nl, click English and Publication downloads.

Rijkswaterstaat 1961. Verslag over de stormvloed van 1953.Rijkswaterstaat, Koninklijk Nederlands Meteorologisch Instituut, Staatdrukkerij en uitgeverijbedrijf 's-Gravenhage 1961 (in Dutch); Report on the stormsurge of 1953.

TAW 2001. Technisch Rapport Waterkerende Grondconstructies, Geotechnische aspecten van dijken, dammen en boezemkaden, Technische Advies Commissie voor de Waterkeringen (in Dutch); 
Technical Report on soil based water defences, geotechnical aspects of dikes, levees and regional defences. Technical Advisory Committee for Water Defences.

TAW 2002, Technical report on wave run-up and wave overtopping, Technical Advisory Committee for Water Defences, May 2002

TAW 1996, Technisch Rapport Klei voor Dijken (In Dutch), Technical report on the use of clay for dikes, Technical Advisory Committee for Water Defences, May 1996

Van Hoven, A. 2008, Sterkte van Kleibekleding bij Golfoverslag, invloed van gras en bodemstructuur op de sterkte van klei (in Dutch), Strength of clay cover layers, the influence of grass and soil structure on the shear strength of clay, Delft Cluster, rapnr. 418020.0011, april 2008

Van Hoven, A., Barends, F.B.J., 2010, A practical approach for infiltration tests, Proceedings FSST 2010

Van der Meer J.W., G.J. Steendam, G. de Raat, P. Bernadini, 2008. Further developments on the wave overtopping simulator, ASCE, proc. ICCE, Hamburg

Van der Meer, J.W., W. Snijders and E. Regeling, 2006. The wave overtopping simulator. ASCE, proc. ICCE, San Diego. 